\title{
The iatrogenic triad in a group of elderly women contracted to a health plan
}

Henrique Souza Barros de Oliveira' $\mathbb{I D}^{-}$ Maria Elisa Gonzalez Manso', $\mathbb{1 D}$

\section{Abstract}

Objective: to study the main elements of the iatrogenic triad in a group of elderly women with a Chronic Non-Communicable Disease (CNCD) contracted to a health plan. Method: A cross-sectional and descriptive epidemiological study was carried out by analyzing 3,501 medical prescriptions of 725 elderly women aged $\geq 65$ years. The medications were determined to be Potentially Inappropriate Medications (PIM) based on four instruments (AGS Beers 2015, PRISCUS List, EU(7)-PIM, Brazilian Consensus of PIM - CBPIM). In addition, the most prescribed drugs were assessed for possible Drug Interactions (DI) and classified according to degree of severity. Results: the present study revealed that $89.3 \%$ of the studied group used at least one element of the iatrogenic triad, and $44.9 \%$ of the sample were associated with the use of polypharmacy and PIM. A total of $48.0 \%$ were taking at least five continuous use medications. The main DI were omeprazole, simvastatin and levothyroxine, all of which are of significant severity and have potential drug-food interactions. A total of $35.1 \%$ of PIM were identified through the four criteria used, $26.6 \%$ were identified by the CBPIM, $25.8 \%$ by the EU(7)-PIM, and $24.6 \%$ and $6.6 \%$ by AGS Beers and PRISCUS, respectively. Conclusion: a high index of continuous use medications, PIM and potential DI were identified, mainly enzymatic inhibitors in a group of elderly women at risk due to their clinical characteristics. Old age was associated with the presence of all the elements of the iatrogenic triad. It was also noted that there were no significant differences between the criteria applied, except for the PRISCUS list.

Keywords: Old Age Assistance. Prescription Drug Overuse. Potentially Inappropriate Medication List. Drug Interactions. Prepaid Health Plans. Public Health.

\footnotetext{
Centro Universitário São Camilo, Faculdade de Medicina. São Paulo, São Paulo, Brasil.

2 Pontifícia Universidade Católica de São Paulo. São Paulo, São Paulo, Brasil. 


\section{INTRODUCTION}

The elderly are the most frequent consumers of medications yet at the same time are the most sensitive and exposed to Adverse Drug Related Events (ADRE) such as: prescription or drug cascades; toxic effects; the Iatrogenic triad, defined as the prescription of at least one potentially inappropriate medication (PIM), combined with the continued use of polypharmacy and the presence of potential drug interactions, and adverse drug reactions (ADR). It is estimated that $30 \%$ of the healthcare appointments of this age group are related to problems with medications ${ }^{1,2}$.

A variety of drugs sold to and consumed by the elderly are associated with the emergence of several types of drug interactions (DI), namely: drug-drug, drug-disease, drug-laboratory test, drug-food and drug-tobacco interactions. Thus, a pharmacological or clinical response where the effects of a drug are altered by the combination of two or more drugs, herbal remedies, food, alcoholic beverages or environmental chemical agents defines the presence of $\mathrm{DI}^{3}$.

ADR are considered to be a harmful and nonintentional response to the use of a drug whose dosage is normally used for prophylaxis or the diagnosis or treatment of diseases. Diuretics, antilipidemics, betablockers, anti-inflammatories, digitalis, inhibitors (omeprazole, cimetidine and captopril) and enzyme inducers (phenytoin and carbamazepine) are some of the medicines that frequently cause ADR and are responsible for approximately $25 \%$ of resulting hospital admissions, which are mostly caused by an acute reaction ${ }^{4,5}$.

Polypharmacy, which is considered the continuous and simultaneous use of at least five different types of drugs, potentiates the therapeutic risk of potential DI, the prescription of PIM and the causing of ADR. PIM are medications prescribed by physicians which present a risk of causing adverse effects which exceed their benefits, and where there effective alternatives to their use exist. The increased risk of adverse reactions, the use of medications that aggravate the underlying disease or the lack of scientific evidence about the therapeutic efficacy of the medication can also be considered PIM ${ }^{1,4,5,6}$.
Faced with this problem, groups of specialists have proposed instruments (criteria) that allow the detection of drugs that are potentially iatrogenic for the geriatric population, considering the degree of evidence for the use of each drug. Each instrument corresponds to the standards of commercialization and the prescription profiles of each country, and include criteria from France, Germany, Australia, Norway, Canada, the United States, England, South Korea and, more recently, Brazil'. The best known instruments are the Beers Criteria ${ }^{8}$, the Screening Tool of Older Person's Prescriptions - STOPP/ Screening Tool to Alert Doctors to Right Treatment - START ${ }^{9}$, Fit for the Aged - FORTA ${ }^{10}$ and the PRISCUS List ${ }^{11}$.

Although some European countries provide their own criteria, in 2015 the European Union developed the European List of Potentially Inappropriate Medications - EU(7)-PIM. This is an up-to-date instrument with a high level of revision, and contains 282 substances contraindicated for use in the elderly. Unlike other instruments, this list provides therapeutic alternatives to clinicians, which facilitates the replacement of PIM ${ }^{12}$.

The Beers Criteria were developed and published by the North American geriatrician Dr. Mark Howard Beers in 1991 to classify the main PIM in use by elderly people living in a long-term care facility. In 1997, the instrument was reviewed and expanded and in 2003 it was adapted for use in several other geriatric services. As of 2012, the American Geriatric Society (AGS) began to participate in periodic reviews, adding quality assessments to the scientific evidence, strengthening these recommendations and helping to disseminate the criteria. The latest review, published in 2015, included a list of potential associated interactions, drugs to be avoided, and those that should have their dosages adjusted based on their renal function in elderly individuals ${ }^{8}$.

Based on the content of the Beers Criteria 2012 and the Screening Tool of Older Persons' Prescriptions (STOPP) 2006, the first Brazilian Consensus on Potentially Inappropriate Medications (CBMPI) was validated and published for use in the elderly. This instrument was created with the aim of improving the quality and safety of the prescriptions of elderly people susceptible to ADRE ${ }^{13}$. 
Studies have shown that the criteria for the verification of drugs which are inappropriate for use with the elderly, as well as the systematic investigation of drug interactions, are still little used in Brazil, especially by the medical profession. In addition to the need to educate and raise the awareness of health professionals working in elderly health care, the use of lists of criteria and programs for detecting DIs, most of which are free and easy to access, along with close collaboration between medical professionals has been found to be effective in reducing potential harm to elderly patients ${ }^{14,15}$.

Despite these efforts, there is still a lack of research exploring the pharmacological issues of the elderly in the Brazilian supplementary health sector. This is a probable risk group for ADRE, as they have quick and easy access to a wide range of health services. The present study aimed to investigate the presence of elements of the Iatrogenic Triad (PIM prescription, continuous use of polypharmacy and the presence of the main potential interactions associated with medication) in a group of elderly women participating in a disease management program, who were contracted to a health plan in the city of São Paulo, Brazil.

\section{METHOD}

Between September and December 2015, a cross-sectional, descriptive, retrospective study was conducted on the use of drugs by a group of noninstitutionalized elderly women, contracted to a supplementary health plan in the city of São Paulo, and who were part of a chronic disease management program $(\mathrm{CDM})$ provided by a health plan provider (HPP) in that city.

All the prescriptions provided to this group of women during the study period were analyzed. The women surveyed were all the elderly women participating in the program, the inclusion criterion of which was age $\geq 65$ years, the age range stipulated by the health plan provider.

\section{Characterization of CDM program}

In 2005, the national health agency (NHA), which is responsible for defending the public interest in the supplementary health care sector, ordered that HPP offer health promotion and disease prevention programs in response to a change to the pattern of illness of the population. Since then, resolutions have been issued that aim to encourage the implementation and maintenance of such programs by these companies ${ }^{16}$.

These programs should be implemented for a population with a risk profile by instituting actions and multiprofessional coordination, ensuring follow-up, evaluation and continuous monitoring of participants via health indicators. Some operators, mostly multi-nationals, have executed such programs through the methodology of disease management $(\mathrm{DM})$ or $\mathrm{CDM}^{16}$.

The CDM program is designed with the goal of promoting health and preventing chronic diseases. To this end, it seeks to increase the involvement of the elderly with their illness(s), stimulating selfcare, preventing acute crises and complications of chronic non-communicable diseases (CNCD), hoping to beneficially affect the natural course of the disease. This program involves monthly telephone monitoring and home visits, the frequency of which depends on the complexity of the case of each elderly person receiving care. Both actions are performed by trained nurses. Adherence to the program is voluntary and, if there is interest in participating, there is no time limit for participation ${ }^{16}$.

All participants in this program must have at least one diagnosed $\mathrm{CNCD}$, in addition to being $\geq 65$ years of age and be receiving medical follow-up care and treatment for their illness. It should be noted that the physicians who accompany these elderly people have no relationship or interaction with the program, and the elderly choose them freely through the service provided by the health plan itself.

\section{Exclusion criteria}

Only elderly women using single medication were excluded from the study as they did not present a risk of drug interaction. In addition, the medical prescriptions of products such as moisturizing creams, eye drops, sunscreens, vitamins, herbal products and medicines in formulas were excluded. 
Study variables

The study variables were age; number and type of drugs prescribed for the elderly; potential DI and severity, and the presence of PIM according to the following instruments: AGS Beers Criteria 2015, PRISCUS list ${ }^{11}$, the European Union PIM list - EU(7)$\mathrm{PIM}^{12}$ and the Brazilian Consensus of PIM - CBMPI ${ }^{13}$. In this way, it was possible to analyze the prevalence and concomitance of the elements that make up the Iatrogenic Triad, as well as their distribution according to age group (65-69, $70-79$ and $\geq 80$ years).

\section{Methodological development}

During the activities of the previously mentioned program, information was collected on the medical prescriptions provided to this group and included in an electronic database. The inclusion of all medical prescriptions provided, by more than one specialist and used by the group were analyzed because of the high frequency of fragmented healthcare provided to the elderly. In addition, some medical prescriptions had been active since 1971, and had been updated regularly in terms of the posology and date of prescription until the year of collection. The descriptive analysis comprised categorical and continuous measures, the latter expressed in the form of measures of central tendency and dispersion measures. The categorical data were expressed by absolute (n) and relative (\%) frequency distribution.

All drugs were analyzed according to the Anatomical Therapeutic Chemical Classification $(\text { ATC })^{17}$.

The ATC classification is recognized and recommended by the World Health Organization (WHO) as an international standard for drug use studies. This classification system divides medications into different levels according to the organ or system in which they act (1st level) and their therapeutic (2nd level), pharmacological (3rd level) and chemical (4th and 5th level) properties ${ }^{17}$.

All the medications analyzed were classified according to the ATC and divided according to the anatomical group or main system in which they act (1st level). To identify the substances from their trade names, a pharmaceutical specialty dictionary (PSD) was used. Medications without a specific ATC code were classified as far as possible by identifying the group, class or therapeutic action.

The prescriptions were classified as polypharmacy or otherwise through the number of drugs prescribed, based on a minimum of five or more drugs in continuous use by the elderly. It should be noted that despite the presence of several definitions of polypharmacy, both qualitative and quantitative, and the lack of consensus, the present study opted for the definition of prevalence applied in literature and commonly used in clinical practice ${ }^{1,2,4,5}$.

Potential drug interactions were identified through three software programs available online, initially by Medscape ${ }^{\circledR}$ (Drug Interaction Checker), followed by confirmation via Micromedex ${ }^{\circledR}$ (University of Maryland Medical Center Drug Checker) and Drugs. $\operatorname{com}^{\circledR}$ (Drug Information Online). All interactions were validated according to their potential severity and confirmed by the programs to increase the accuracy of the information. The researchers opted to use the Medscape ${ }^{\circledR}$ software to analyze the impact of the interactions associated with medication as it is a widely used and accepted program and is considered the gold standard in this segment. In cases of disagreement between the databases regarding the classification of interaction, the lower classification of severity was adopted. Based on the information available in the databases consulted, only the most prevalent drugs were described and classified for severity, and the DI could be considered non-significant, significant and highly significant.

To determine PIM regardless of diagnosis and clinical condition, the Beers Criteria 2015, PRISCUS list, EU(7)-PIM and CBMPI were used. The selection of these criteria was based on the prevalence of use in literature and the fact that they covered different regions of the world. In terms of screening, PIM was considered present when identified by any of the criteria mentioned above.

\section{Ethical assumptions}

The study was explained to all the participants in the study, who were also informed about the 
voluntary, optional nature of their involvement and the confidentiality of their data. After signing a Free and Informed Consent Form (FICF), a team of nurses collected the data in the patients' homes during the CDM program activities. The research project was approved by the Research Ethics Committee of the Centro Universitário São Camilo, SP, CAAE: 48122015.7.0000.0062.

\section{RESULTS}

Prescriptions were given to 725 elderly women contracted to a health plan in the city of São Paulo, whose mean age was $77.9( \pm 7.37)$ years, ranging from 65 to 101 . Longevity was observed in the studied group, as $41.1 \%$ were $70-79$ years old and $40.4 \%$ were aged $\geq 80$ years.

A total of 3,501 drugs were prescribed by physicians, with an average of 5.8 ( \pm 2.49$)$, ranging from two to 13 drugs/elderly woman, with a median of 6 and an interquartile between 4 and 7. The prevalence of elderly women taking $\geq 5$ drugs on a concomitant and continuous use basis was $48.8 \%$ (348). When analyzing mean drug consumption versus age range, a maximum mean of polypharmacy of $6.1( \pm 2.51)$ was observed in elderly women aged $\geq 80$ years, as shown in Table 1 .

The three most prevalent DI with significant severity were simvastatin versus omeprazole (151; $20.8 \%$ ), simvastatin versus levothyroxine (120; $16.5 \%$ ) and omeprazole versus levothyroxine (108; 14.8\%). All three drugs mentioned presented a potential drug-food interaction risk, with omeprazole and levothyroxine having significant severity and simvastatin highly significant severity. The distribution of the most prevalent DI according to age, severity level and potential ADR are shown in Table 2.

Table 1. Analysis of medical prescriptions according to the number of medications, age and presence of continuous use medication, of a group of elderly women contracted to a health plan in the city of São Paulo, Brazil, 2015.

\begin{tabular}{llll}
\hline & $\mathrm{n}(\%)$ & Age & Continuous use medications \\
\hline 65-69 years & $134(18.5 \%)$ & $67.1( \pm 1.5)$ & $5.0( \pm 1.9)(02-10)$ \\
$70-79$ years & $298(41.1 \%)$ & $74.8( \pm 2.6)$ & $5.8( \pm 2.6)(02-13)$ \\
$\geq 80$ years & $293(40.4 \%)$ & $84.9( \pm 4.0)$ & $6.1( \pm 2.5)(02-13)$ \\
Overall & $725(100 \%)$ & $77.9( \pm 97.3)$ & $5.8( \pm 2.4)(02-13)$ \\
\hline
\end{tabular}

Table 2. Main drug-drug interactions found in prescriptions given to a group of elderly women contracted to a health plan in the city of São Paulo, Brazil, 2015.

\begin{tabular}{|c|c|c|c|}
\hline \multirow[b]{2}{*}{ Variable } & \multicolumn{3}{|l|}{ Drug-drug interactions } \\
\hline & $\begin{array}{l}\text { Simvastatin } \\
\text { versus } \\
\text { Omeprazole } \\
\end{array}$ & $\begin{array}{l}\text { Simvastatin } \\
\text { versus } \\
\text { Levothyroxine } \\
\end{array}$ & $\begin{array}{l}\text { Omeprazole } \\
\text { versus } \\
\text { Levothyroxine } \\
\end{array}$ \\
\hline Severity & Significant & Significant & Significant \\
\hline Potential risk & $\begin{array}{l}\text { Serum increase of simvastatin } \\
\text { leading to myopathy } \\
\text { (rhabdomyolysis) and liver } \\
\text { disease }\end{array}$ & \multicolumn{2}{|c|}{$\begin{array}{l}\text { Decreased therapeutic efficacy of levothyroxine leading to } \\
\text { adverse effects (fatigue, drowsiness, constipation, weight } \\
\text { gain, feelings of depression, low temperature intolerance, } \\
\text { cutaneous and capillary xerosis) }\end{array}$} \\
\hline \multicolumn{4}{|c|}{ e } \\
\hline 65-69 years & $27(3.7 \%)$ & $20(2.7 \%)$ & $12(1.6 \%)$ \\
\hline $70-79$ years & $65(8.9 \%)$ & $50(6.8 \%)$ & $38(5.2 \%)$ \\
\hline$\geq 80$ years & $59(8.1 \%)$ & $50(6.8 \%)$ & $58(8 \%)$ \\
\hline Total & $151(20.8 \%)$ & $120(16.5 \%)$ & $108(14.8 \%)$ \\
\hline
\end{tabular}


All the drugs were analyzed and determined as appropriate or potentially inappropriate. For this, four screening instruments were used, as mentioned, and all were grouped as PIM. It was found that 81.1\% (588) of the studied women use at least one PIM, with an average of $2.8( \pm 1.43) \mathrm{PIM} /$ elderly woman and a median of 3 [IQ 2-4] PIM/elderly woman.

All 1,232 (35.1\%) PIMidentified by the four criteria were grouped, analyzed and classified according to the ATC classification. A high prevalence of prescriptions for the digestive system and metabolism (494; 40.0\%) was observed, followed by for the central nervous system $(351 ; 28.4 \%)$, cardiovascular system (128; 10.3\%), skeletal muscle system $(107,8.6 \%)$ and blood and hematopoietic organs $(55,4.4 \%)$. The groups with the lowest prevalence were systemic use hormones and antiparasitic products $(<0.1 \%)$. Table 3 presents the main PIM as defined by the ATC classification, according to the age group of the studied group.

A high prevalence of prescriptions of PIM, defined in accordance with the CBMPI $(932 ; 26.6 \%)$, the EU(7)-PIM (904; 25.8\%) and the Beers Criteria $(864,24.6 \%)$ was also observed. The PRISCUS list identified only 6.6\% (233) of PIM (Table 4). The mean number of PIM per elderly person was 2.2 \pm 1.21 (1-7) according to the CBMPI, 2 ( \pm 1.02$)$ (1$5)$ according to the EU(7)-PIM, 1.9 ( \pm 1.01$)(1-5)$ according to the Beers Criteria and 1.3 ( \pm 0.54$)$ (13) according to the PRISCUS list. The main PIMs prescribed to the group were omeprazole, insulin, furosemide, clonazepam, promethazine and aspirin.

Table 3. Anatomical Therapeutic Chemical Code (ATC) classification of the main potentially inappropriate medications according to age, prescribed to a group of elderly women linked to a health plan of the city of São Paulo, Brazil, 2015.

\begin{tabular}{lllll}
\hline Code & Systems & $\mathrm{n}(\%)$ & $\mathrm{n}(\%)$ & $\mathrm{n}(\%)$ \\
\cline { 3 - 5 } & & $65-69$ years & $70-79$ years & $\geq 80$ years \\
\hline $\mathrm{A}$ & Digestive system and metabolism & $85(6.8)$ & $213(17.2)$ & $196(15.9)$ \\
\hline $\mathrm{B}$ & Blood and Hematopoietic Organs & $08(0.6)$ & $22(1.7)$ & $25(2.0)$ \\
\hline $\mathrm{C}$ & Cardiovascular system & $11(0.8)$ & $50(4.0)$ & $67(5.4)$ \\
$\mathrm{D}$ & Dermatological & $03(0.2)$ & $07(0.5)$ & $10(0.8)$ \\
\hline $\mathrm{G}$ & Genito-urinary system and sex hormones & $08(0.6)$ & $14(1.1)$ & $07(0.5)$ \\
\hline $\mathrm{H}$ & Systemic use hormones, excluding sex hormones & - & - & $01(0.08)$ \\
\hline $\mathrm{J}$ & General anti-infectives for systemic use & $06(0.4)$ & $10(0.8)$ & $11(0.8)$ \\
\hline $\mathrm{M}$ & Muscle skeletal system & $23(1.8)$ & $47(3.8)$ & $37(3.0)$ \\
\hline $\mathrm{N}$ & Central nervous system & $46(3.7)$ & $135(10.9)$ & $170(13.7)$ \\
\hline $\mathrm{P}$ & Antiparasitic Products & - & $01(0.08)$ & - \\
\hline $\mathrm{R}$ & Respiratory system & $06(0.4)$ & $03(0.2)$ & $07(0.5)$ \\
\hline $\mathrm{S}$ & Sense organs & $01(0.08)$ & - & $02(0.16)$ \\
\hline & Total & $197(15.9)$ & $502(40.7)$ & $533(43.2)$ \\
\hline
\end{tabular}


Table 4. Main PIMs identified by the Beers 2015, PRISCUS, CBMPI and EU(7)-PIM criteria, among a group of elderly women contracted to a health plan in the city of São Paulo, Brazil, 2015.

\begin{tabular}{|c|c|}
\hline $\mathrm{n}$ & $\begin{array}{l}233(6.6 \%) \text { PIM, according to the PRISCUS list } \\
189 \text { elderly persons }(26 \%) \text { used at least one PIM identified by these criteria }\end{array}$ \\
\hline 41 & Bromazepam \\
\hline 20 & Alprazolam \\
\hline 18 & Fluoxetine \\
\hline 17 & Zolpidem \\
\hline 15 & Nitrofurantoin \\
\hline 12 & Meloxicam \\
\hline 09 & Sotalol \\
\hline 09 & Oxybutynin/Dimenhydrinate \\
\hline 07 & Ticlopidine \\
\hline \multirow[t]{3}{*}{06} & Methyldopa/Pentoxifylline \\
\hline & $864(24.6 \%)$ PIM, according to Beers 2015 criteria \\
\hline & 480 elderly women $(66.2 \%)$ used at least one PIM identified by this criteria \\
\hline 336 & Omeprazole \\
\hline 71 & Insulin \\
\hline 50 & Clonazepam \\
\hline 44 & Promethazine \\
\hline 42 & Aspirin \\
\hline 27 & Orphenadrine/Quetiapine \\
\hline 22 & Diclofenac \\
\hline 20 & Alprazolam \\
\hline 19 & Carisoprodol \\
\hline \multirow[t]{3}{*}{17} & Zolpidem \\
\hline & 904 (25.8\%) PIM, according to EU(7)-PIM \\
\hline & 516 elderly women $(71.1 \%)$ used at least one PIM identified by this criteria \\
\hline 336 & Omeprazole \\
\hline 71 & Insulin \\
\hline 50 & Clonazepam \\
\hline 44 & Promethazine \\
\hline 41 & Bromazepam \\
\hline 23 & Glimepiride/Sitagliptin \\
\hline 22 & Diclofenac \\
\hline 20 & Alprazolam \\
\hline 18 & Fluoxetine \\
\hline \multirow[t]{3}{*}{17} & Zolpidem \\
\hline & $932(266 \%)$ PIMs, according to CBMPI \\
\hline & 525 elderly persons $(72.4 \%)$ used at least one PIM identified by this criteria \\
\hline 336 & Omeprazole \\
\hline 58 & Furosemide \\
\hline 50 & Clonazepam \\
\hline 44 & Promethazine \\
\hline 42 & Aspirin \\
\hline 27 & Quetiapine \\
\hline 22 & Diclofenac \\
\hline 20 & Alprazolam \\
\hline 19 & Carisoprodol \\
\hline 17 & Prednisone/Zolpidem \\
\hline
\end{tabular}

PIM: Potentially inappropriate medications;

EU(7)-PIM: EU list of potentially inappropriate medications;

CBMPI: Brazilian consensus of potentially inappropriate medications. 
The analysis of the elements of the Iatrogenic Triad revealed that $89.3 \%$ (648) of the elderly women met at least one element of the same, and $44.9 \%$ (326) were associated with the continuous and simultaneous use of polypharmacy and PIM. Of these, $46.0 \%$ (150) corresponded to elderly women aged $\geq 80$ years, $38.3 \%$ (125) to elderly women aged 70-79 years, while the lowest number, 15.6\% (51), were aged from 65 to 69 years.

\section{DISCUSSION}

In recent years, a Brazilian demographic phenomenon has attracted the attention of researchers: the high prevalence of the female gender in the geriatric population. The latest data, published in 2018, from the Brazilian Institute of Geography and Statistics (IBGE), show that women make up the majority of this age group, with 16.9 million (56\% of the sector), compared to 13.3 million elderly men $(44 \%)$. Elderly women $\geq 80$ years old are twice as numerous as men of the same age, while there are four to five times more women than men aged 100 or over ${ }^{18}$. In terms of the demographic characteristics of elderly persons receiving care from the Brazilian supplementary health sector, the greatest coverage is among female elderly persons, in the age group between 70 and 79 years, mainly in the southeast of Brazil, data concordant with the findings of this sample ${ }^{19}$.

The female gender remains a constant risk factor for numerous conditions in advanced age, such as the continuous and concomitant use of $\geq 5$ medications (polypharmacy), the use of psychotropic drugs and $\mathrm{PIM}^{20,21}$. According to national studies conducted with elderly people from this segment, the general average daily consumption of medication per elderly person ranges from 3.5 to 5.9. When consumption among elderly women was investigated, a higher average than the overall group, which was similar to the data found in the present study, was identified ${ }^{22,23}$.

As described, the group of elderly women participating in the present study are part of a program for which, as an inclusion criterion, the diagnosis of at least one CNCD is required. This determines the greater clinical and therapeutic vulnerability of the group, highlighting the importance of avoiding the irrational use of medications, especially those considered potentially inappropriate. Thus, the risk of the occurrence of ADR, illness, decompensation of the underlying disease(s), profiles of confusion (delirium), dependence, hospitalization and institutionalization increases significantly ${ }^{5,23}$.

The main interactions found in the studied population were between omeprazole, simvastatin and levothyroxine, and all were classified as of moderate or significant severity. The DI found are related to enzyme inducer or inhibitor medications, mechanisms which favor the development of DI and the combinations of which should be avoided as they involve pharmacokinetic processes of the hepatic inhibition of other $\operatorname{drugs}^{24,25}$.

The combination of omeprazole and simvastatin was present in $20.8 \%$ of prescriptions, resulting in an interaction of significant severity. These medicinal products are administered concomitantly in hospitalized and outpatient clinical practice, especially for long-term outcomes in patients at risk of cardiovascular events. The sole prescription of HMG-coa reductase inhibitors involves a risk of myopathy, especially rhabdomyolysis, a pathological condition which may be increased when combined with antimicrobials (azithromycin, ciprofloxacin, clarithromycin and fluconazole). When combined, these drugs may lead to the competitive inhibition of intestinal $\beta$-glycoprotein and biotransformation by CYP4503A4 and/or cytochrome P450, resulting in increased plasma concentrations of simvastatin, augmenting the risk of side effects such as liver damage, muscle tissue degradation leading to rhabdomyolysis and acute renal injury. During the evaluation of these patients, the clinical nonspecificity of the condition may lead to underdiagnosis and thus, a delay to the correct management of the condition $^{24-26}$.

The combination of simvastatin and omeprazole with levothyroxine leads to a reduction in the therapeutic efficacy of levothyroxine. Levothyroxine is the synthetic form of the thyroid hormone thyroxine (T4) and is used for hormone replacement in cases of hypothyroidism, regardless of the etiology. This synthetic hormone should be administered in 
the morning after fasting, one hour before breakfast, due to the potential risk of drug-food interaction. The reduced therapeutic efficacy of levothyroxine may lead to adverse effects such as tiredness, drowsiness, constipation, weight gain, feelings of depression, low temperature intolerance, cutaneous and capillary xerosis. In the long term, serum levels of cholesterol, homocysteine, and C-reactive protein increase. There is also a risk of bone fractures and increased arterial stiffness, which becomes a significant risk factor for cardiovascular diseases ${ }^{27}$.

It should be noted that the administration of simvastatin, levothyroxine and omeprazole near meal times should be contraindicated. These also a significant risk of drug-food interaction, as the reduction in the rate of drug absorption slows gastric emptying, causing interactions that lead to harm. Therefore, respecting the gaps between the administering of these drugs and meals is important for the bioavailability of the impact of the medication ${ }^{28}$.

Proton pump inhibitors (PPI), such as omeprazole, are commonly prescribed drugs for the treatment of gastroesophageal reflux disease, esophagitis, gastritis, peptic ulcers, gastrointestinal bleeding, and gastric protection. However, use for more than eight weeks is contraindicated and inappropriate, due to the potential for the development of loss of bone mass leading to osteoporosis and fractures, dementia, renal injury, pneumonia, altered gastric $\mathrm{pH}$ favoring Clostridium difficile infections, hydroelectrolytic disorders (hypomagnesaemia, hypokalemia) and even vitamin B12 and iron deficiency due to gastric atrophy and malabsorption. The prolonged use in the elderly with Helicobacter pylori infection or with successful eradication is associated with an increased risk of developing gastric neoplasia. In addition, the use of PPI concomitantly with other drugs represents a high risk for DI, and these drugs should be prescribed with caution ${ }^{8,12,13,29,30}$.

It is important to note the high prevalence of PIM in the studied group, similar to that described in literature for elderly people in this health sector, with a prevalence ranging from 11.7 to $41.9 \%{ }^{20}$ $, 21,27$. However, when assessing hospitalized or institutionalized elderly persons or only those in outpatient follow-up care, there is great variability in the prevalence of PIM $(2.9 \%$ to $91.9 \%),{ }^{30,31}$.

Despite the large number of criteria for PIM screening available, not many are applicable in different regions of the world, and few studies have compared these criteria to determine their differences, applicability or ability to identify PIM. The present study applied four criteria from different regions of the world (the USA, the European Union, Germany and Brazil) and found similarities in prevalence among CBMPI, EU(7)-PIM and AGS Beers 2015. The PRICUS list identified a low prevalence of PIMs in the sample studied. In a study by Novaes et al. ${ }^{28}$, a high prevalence of PIM (50\% for AGS Beers 2015 and 59.5\% for EU(7)-PIM) was found among Brazilian elderly persons residing in the community. This same study found a high degree of agreement between the criteria and noted that the EU(7)-PIM criterion had greater sensitivity and the Beers had a more balanced profile between specificity and sensitivity. However, further studies in Brazil should be carried out.

The use of more than one instrument for screening in the present study allowed more accurate PIM screening, as each of the instruments has flaws for the reality of Brazil. It is worth mentioning the importance of periodic reviews, the insertion of other medications that are widely used by the Brazilian geriatric population and an annex with therapeutic alternatives. In addition, the participation/ partnership of the Brazilian Society of Geriatrics and Gerontology (SBGG) in the reviewing and divulgation of this instrument for professionals in the area is of the utmost importance.

When the presence of at least one element of the Iatrogenic Triad was analyzed, it was observed that $89.3 \%$ of these elderly women used PIM, polypharmacy or potentially interacting drugs, and it was noted that $44.9 \%$ used at least two elements of the triad on a daily basis.

These data, associated with the high prevalence of PIM (35.1\%) in this group and the excessive use of prescribed medications $(48.8 \%)$, are a concern 
for the researchers. The findings, added to the advanced age identified and the presence of chronic conditions, make the studied group highly susceptible to unfavorable outcomes of ADRE.

\section{Limitations}

It should be noted that the present study has some limitations. The sociodemographic and clinical particularities of risk in the studied group make it impossible to generalize and compare the results obtained. Furthermore, elderly women who used two or more drugs were included in the study as they presented a risk of drug interaction, leading to an overestimation of the results obtained by measures of central tendency in terms of the number of drugs prescribed. Due to the lack of analysis of the type and number of diagnoses of the elderly, it was not possible to state whether the findings were harmful to this group. It is also worth noting that functional deterioration, self-medication, interaction with underlying disease(s), the occurrence of ADR and the outcome of the ADRE (institutionalization, hospitalization or death) were not evaluated in the present study.

\section{REFERENCES}

1. Gorzoni ML. Geriatria: medicina do século XXI?. Medicina (Ribeirão Preto). 2017;50(3):144-9.

2. Novaes PH, Cruz DT, Lucchetti ALG, Leite ICG, Lucchetti G. The "iatrogenic triad": polypharmacy, drug-drug interactions, and potentially inappropriate medications in older adults. Int J Clin Pharm. 2017;39(4):818-25.

3. Scrignoli CP, Teixeira VCMC, Leal DCP. Interações medicamentosas entre fármacos mais prescritos em unidade de terapia intensiva adulta. Rev Bras Farm Hosp Serv Saúde. 2016;7(2):26-30.

4. Vera ECBA. Terapia medicamentosa do idoso: fatores de influência [dissertação na Internet]. São Paulo: Pontifícia Universidade Católica; 2017 [acesso 30 ago. 2018]. Disponível em: https://tede2.pucsp.br/ bitstream/handle/19829/2/Elaine\%20Cristina\%20 Biffi $\% 20$ Alonso $\% 20$ Vera.pdf

5. Oliveira HSB, Corradi MLG. Aspectos farmacológicos do idoso: uma revisão integrativa de literatura. Rev Med (São Paulo). 2018;97(2):165-76.

\section{CONCLUSION}

The present study identified a high level of Potentially Inappropriate Medications and the taking of continuous use drugs - mainly enzymatic inhibitors - as well as a significant risk for the development of drug interactions in a group of elderly women with chronic non-communicable diseases contracted to a health plan in the city of São Paulo, Brazil. The advanced age of the group and the high prevalence of elements of the Iatrogenic Triad were concerning. The association between the demographic and clinical characteristics of the investigated group also predisposes the further association of these findings with functional deterioration, prescription cascades, hospitalization and morbidity and mortality.

There was no difference in the prevalence of potentially inappropriate drugs identified by the criteria used in this study, except for the PRISCUS list. Although the Brazilian Consensus on Potentially Inappropriate Medications, the European List of Potentially Inappropriate Medications and the Beers 2015 Criteria have been found to be effective, the application of more than one instrument seems to have allowed greater screening accuracy.

6. Lutz BH. Inadequação do uso de medicamentos entre idosos na cidade de Pelotas, RS [dissertação na Internet]. Pelotas: Universidade Federal de Pelotas; 2015 [acesso em 20 ago. 2018]. Disponível em: http://www.epidemioufpel.org.br/uploads/teses/dissert\%20barbara.pdf

7. Nam YS, Han JS, Kim JY, Bae WK, Lee K. Prescription of potentially inappropriate medication in Korean older adults based on 2012 Beers Criteria: a cross-sectional population based study. BMC Geriatrics. 2016;16:1-9.

8. American Geriatrics Society. American Geriatrics Society 2015 Beers Criteria for potentially inappropriate medication use in older adults. J Am Geriatr Soc. 2015;63(11):2227-46.

9. O’Mahony D, O'Sullivan D, Byrne S, O'Connor MN, Ryan C, Gallagher P. STOPP/START criteria for potentially inappropriate prescribing in older people: Version 2. Age Ageing. 2015;44(2):213-8. 
10. Kuhn-Thiel AM, Weib C, Wehling M. Consensus validation of the FORTA (Fit fOR The Aged) List: a clinical tool for increasing the appropriateness of pharmacotherapy in the elderly. Drugs Aging. 2014;31(2):131-40.

11. Holt S, Schmiedl S, Thurmann PA. Potentially inappropriate medications in the elderly: The PRISCUS list. Dtsch Arztebl Int. 2010;107(31-32):543-51.

12. Guiteras AR, Meyer G, Thurmann PA. The EU(7)-PIM list: a list of potentially inappropriate medications for older peolpe consented by experts from seven European countries. Eur J Clin Pharmacol. 2015;71(7):861-75.

13. Oliveira MG, Amorim WW, Oliveira CRB, Coqueiro HL, Gusmão LC, Passos LC. Consenso brasileiro de medicamentos potencialmente inapropriados para idosos. Geriatr Gerontol Aging. 2017;10(4):168-81.

14. Leão DFL, Moura CS, Medeiros DS. Avaliação de interações medicamentosas potenciais em prescrições da atenção primária de Vitória da Conquista (BA), Brasil. Ciênc Saúde Colet. 2014;19(1):311-8.

15. Cedraz KN, Santos Junior MC. Identificação e caracterização de interações medicamentosas em prescrições médicas da unidade de terapia intensiva de um hospital público da cidade de Feira de Santana, BA. Rev Soc Bras Clin Med. 2014;12(2):1-7.

16. Manso MEG, Câmara R, Souza AS, Maciel TD, Farina DBL. Programa de gerenciamento de doenças crônicas em um plano de saúde, São Paulo, Brasil. Ciênc Cuid Saúde. 2016;15(2):321-27.

17. World Health Organization. Anatomical Therapeutic Chemical. Classification. Index with defined daily doses (DDDs). Oslo: WHO; 2010.

18. Instituto Brasileiro de Geografia e Estatística. Pesquisa Nacional por Amostra de Domicílios (PNAD) contínua: número de idosos cresce $18 \%$ em 5 anos e ultrapassa 30 milhões em 2017 [Internet]. Rio de Janeiro: IBGE; 2018 [acesso em 20 ago 2018]. Disponível em: https://agenciadenoticias.ibge. gov.br/agencia-noticias/2012-agencia-de-noticias/ noticias/20980-numero-de-idosos-cresce-18-em-5anos-e-ultrapassa-30-milhoes-em-2017

19. Manso MEG, Osti AV, Borrozino NF, Maresti LTP. Avaliação multidimensional do idoso: resultados em um grupo de indivíduos vinculados a uma operadora de planos de saúde. Rev Kairós. 2018;21(1):191-211.

20. Manso MEG, Oliveira HSB, Biffi ECA. Gênero e polifarmácia: Impacto em um grupo de idosos vinculados a um plano de saúde. In: $20^{\circ}$ Congresso Brasileiro de Geriatria e Gerontologia; 8-11 de junho de 2016; Fortaleza- CE. Fortaleza: SBGG; 2016. Resumos dos trabalhos científicos aprovados. p. 1233.
21. Martins GA, Acurcio FA, Franceschini SCC, Priore SE, Ribeiro AQ. Medicamentos potencialmente inadequados entre idosos do Município de Viçosa, Minas Gerais, Brasil: um inquérito de base populacional. Cad Saúde Pública. 2015;31(11):2401-12.

22. Muniz ECA, Goulart FC, Lazarini CA, Marin MJS. Analise do uso de medicamentos por idosos usuários de plano de saúde suplementar. Rev Bras Geriatr Gerontol. 2017;20(3):357-87.

23. Manso MEG, Biffi ECA, Gerardi TJ. Prescrição inadequada de medicamentos a idosos portadores de doenças crônicas em um plano de saúde no município de São Paulo, Brasil. Rev Bras Geriatr Gerontol. 2015;18(1):151-64.

24. Iamaguchi FM, Crozatti MTL, Bertolini DA, Demarchi IG, Okawa RTP, Teixeira JJV. Frequência de interações potenciais medicamento-medicamento em prescrições médicas na atenção primária em saúde. Rev UNINGÁ. 2017;29(1):54-60.

25. Ribeiro Neto LM, Costa Junior VL, Crozara MA. Interações medicamentosas potenciais em pacientes ambulatoriais. Mundo Saúde. 2017;41(1):107-15.

26. Alvim MM, Silva LA, Leite ICG, Silvério MS. Eventos adversos por interações medicamentosas potenciais em unidade de terapia intensiva de um hospital de ensino. Rev Bras Ter Intensiva. 2015;27(4):353-9.

27. Ward LS. Levotiroxina e o problema da permutabilidade de drogas de estreito intervalo terapêutico. Arq Bras Endocrinol Metab. 2011;55(7):429-34.

28. Peixoto JS, Salci MA, Radovanovic CAT, Salci TP, Torres MM, Carreira L. Riscos de interação droga-nutriente em idosos de instituição de longa permanência. Rev Gaúcha de Enferm. 2012;33(3):156-64.

29. Oliveira HSB, Sousa JRP, Donis ACG, Manso MEG. Utilização dos critérios de Beers para avaliação das prescrições em idosos portadores de doenças crônicas vinculadas a um plano de saúde. Rev Bras Ciênc Envelhec Hum. 2017;14(3):242-51.

30. Novaes PH, Cruz DT, Lucchetti ALG, Leite ICG, Lucchetti G. Comparison of four criteria for potentially inappropriate medications in Brasilian community-dwelling older adults. Geriatr Gerontol Int. 2017;17(10):1628-35.

31. Santos AHDP, Cusinato CT, Guahyba RS. Medicamentos potencialmente inapropriados (MPIS) para idosos: prevalência em um hospital terciário do Brasil. Rev Bras Farm Hosp Serv Saúde. 2017;8(3):14-8. 